\title{
CHL1 gene polymorphisms increase lung cancer susceptibility
}

\author{
Wen Tian ${ }^{1,2}$, Xuelian Li, ${ }^{1,2}$, Yangwu Ren ${ }^{1,2}$, Zhihua Yin ${ }^{1,2}$, Xiaowei Quan ${ }^{1,2}$, Chang \\ Zheng $^{1,2}$ and Baosen Zhou ${ }^{1,2}$ \\ ${ }^{1}$ Department of Epidemiology, School of Public Health, China Medical University, Shenyang, China \\ ${ }^{2}$ Key Laboratory of Cancer Etiology and Prevention, China Medical University, Liaoning Provincial Department of Education, \\ Liaoning, Shenyang, China
}

Correspondence to: Baosen Zhou, email: bszhou@cmu.edu.cn

Keywords: polymorphism; lung cancer; susceptibility; CHL1

Received: September 30, $2017 \quad$ Accepted: November 16, $2017 \quad$ Published: January 06, 2018

Copyright: Tian et al. This is an open-access article distributed under the terms of the Creative Commons Attribution License 3.0 (CC BY $3.0)$, which permits unrestricted use, distribution, and reproduction in any medium, provided the original author and source are credited.

\section{ABSTRACT}

Lung cancer represents a complex and malignant cancer. Close Homologue of L1 (CHL1) gene plays a crucial role in the progress of cancer. The aim of this study is to explore the association between CHL1 rs425366 polymorphism and lung cancer susceptibility in northeast of China. A hospital-based case-control study was carried out to collect relative characteristics. Logistic regression analysis was conducted to analyze the relationship between single nucleotide polymorphisms and lung cancer susceptibility. The results suggested that there was statistically significant difference between GT genotype and TT genotype of rs425366 and lung cancer susceptibility. In stratified analysis, TT genotype of rs425366 may increase the risk of lung adenocarcinoma. We also found that non-smoking individuals carrying $\mathrm{T}$ allele were more likely to develop lung cancer. Overall, our study may indicate that CHL1 gene may increase lung cancer susceptibility in northeast of China.

\section{INTRODUCTION}

Lung cancer is one of the complicated and malignant diseases, causing 1.8 million new cases and 1.6 million deaths annually in the worldwide [1-3]. In China, the increase of lung cancer hits $1.63 \%$ per year, $1.30 \%$ for men and $2.34 \%$ for women $[4,5]$. In spite of significant breakthrough in the treatment of lung cancer, 5-year survival rate still remains less than $10 \%[6,7]$. As the research moved along, tobacco exposure was considered as one of the potential risk factors for lung cancer [8-11]. However, there are still a large proportion of non-smoking patients suffering from lung cancer in their lifetime [12]. Thus, gene polymorphisms and environmental factors play prominent roles in the process of cancer occurrence, progression and treatment $[13,14]$.

CHL1 gene, on $3 \mathrm{p} 26$, is a neural recognition molecule which may be involved in signal transduction pathways [15, 16]. The protein encoded by CHL1 gene belongs to L1 gene family of neural cell adhesion molecules [17, 18]. For cervical cancer cells, CHL1 gene promoted cell growth, migration and invasion as a target of miR-10a [19]. In human breast cancer cells, the deficiency of CHL1 gene may dysregulate of MAPK and PKA pathways. Finally CHL1 gene promoted cancer cells growth, migration and invasion [20-22]. Other data testified that abnormal expression of CHL1 gene inhibited cancer cells clonogenicity and migration in nasopharyngeal carcinoma [23]. Meanwhile, recent research showed that the up-regulation of CHL1 gene and increase of CHL1 mRNA level were found in lung cancer [17]. Until now, the biological mechanism of CHL1 gene in lung cancer is still an issue. Thus, we investigated the biological function of CHL1 gene.

In this paper, we conducted hospital-based casecontrol study to explore the relationship between CHL1 gene polymorphism and lung cancer susceptibility. Besides, we investigated the association between CHL1 gene polymorphism, tobacco exposure and lung cancer susceptibility.

\section{RESULTS}

\section{Subjects characteristics}

This study consisted of 742 cases and 679 controls, involving 174 smokers and 1005 non-smokers. As Table 1 showed, the mean ages of cases and controls were 
Table 1: Demographic characteristics of cases and controls in northeast of China

\begin{tabular}{|c|c|c|c|c|}
\hline Variables & & Cases (\%) & Controls (\%) & $P$-value \\
\hline \multirow[t]{2}{*}{ Gender } & male & $131(17.66)$ & $129(19.00)$ & \\
\hline & female & $611(82.34)$ & $550(81.00)$ & 0.231 \\
\hline Age (years) & mean $\pm \mathrm{SD}$ & $58.06 \pm 11.306$ & $57.98 \pm 10.625$ & 0.320 \\
\hline \multirow[t]{3}{*}{ Smoke } & never & $627(84.39)$ & $378(55.67)$ & \\
\hline & yes & $108(14.54)$ & $66(9.72)$ & 0.936 \\
\hline & unknown & $8(1.07)$ & $235(34.61)$ & \\
\hline \multirow[t]{4}{*}{ Histology } & adenocarcinoma & $454(61.19)$ & & \\
\hline & squamous cell carcinoma & $164(22.10)$ & & \\
\hline & small cell lung cancer & $92(12.40)$ & & \\
\hline & others & $32(4.31)$ & & \\
\hline
\end{tabular}

$58.06 \pm 11.306$ and $57.98 \pm 10.625$ years, respectively. The results pointed out that there were no significant differences in gender, age and smoking status between cases and controls (Gender: $P=0.231$; Age: $P=0.320$; Smoke: $P=0.936$ ). Lung cancer patients were consisted of 454 adenocarcinomas, 164 squamous cell carcinomas, 92 small cell adenocarcinomas.

\section{SNP frequencies and association with lung cancer}

Table 2 tabulated distribution of rs $425366 \mathrm{G}>\mathrm{T}$ in cases and controls. The genotype frequencies of rs 425366 polymorphism in controls were in accordance with Hardy-Weinberg equilibrium $(P=0.958)$. After adjusting by age and gender, we found statistically significant association of rs425366 polymorphism and lung cancer susceptibility. The result explored that carriers of $\mathrm{T}$ allele had an increased risk of lung cancer compared with homozygous wild allele (T allele: $P=0.018$ ). Moreover, TT genotype of rs425366 had a 1.433 -fold risk of lung cancer susceptibility compared with GT genotype (TT: $P$ $=0.019, \mathrm{OR}=1.433 ; \mathrm{GT}: P=0.031, \mathrm{OR}=1.310)$.

\section{Stratified analysis}

For rs425366 polymorphism, we found statistically significant association between TT genotype and lung adenocarcinoma (TT: $P=0.026, \mathrm{OR}=1.477$ ). In addition, individuals carrying T allele of CHL1 gene had a 1.207fold risk of lung adenocarcinoma (Additive model: $P=$ 0.030 ). Nevertheless, we failed to observe significant differences between squamous cell carcinoma and gene polymorphism (GT: $P=0.257$, OR $=1.271$; TT: $P=$ 0.104, OR $=1.515$; Dominant model: $P=0.145$; $\mathrm{OR}=$ 1.340; Additive model: $P=0.107, \mathrm{OR}=1.224)$. The similar results were also found in small cell lung cancer (GT: $P=0.265$, OR $=1.352$; TT: $P=0.990, \mathrm{OR}=1.004$; Dominant model: $P=0.533$; $\mathrm{OR}=1.168$; Additive model: $P=0.981, \mathrm{OR}=0.996$ ).

\section{Gene-environmental analysis}

Table 4 described the effect of gene-environment on lung cancer susceptibility in northeast of China. The results indicated that non-smoking individuals who carried rs425366 T allele had a 1.248-fold increased risk for developing lung cancer $(P=0.018)$. No significant association was observed between tobacco exposure, rs425366 polymorphism and lung cancer susceptibility.

\section{DISCUSSION}

Gene polymorphism and environmental factors play key roles in lung cancer initiation and progression. We performed this case-control study to estimate the connection between CHL1 gene polymorphism and lung cancer susceptibility. As far as we are aware, this paper firstly investigated the connection between CHL1 gene polymorphism and lung cancer susceptibility. Our results showed that there was statistically significant association between CHL1 rs425366 polymorphism and lung cancer susceptibility in northeast of China. In addition, $T$ allele of rs425366 in CHL1 gene increased lung cancer susceptibility.

rs425366 locates in the intron zone of CHL1 gene, which may not alter the sequence of mRNA and protein [23]. But mutations in rs425366 may modulate CHL1 gene biological function in different human cancer cell lines [23]. CHL1 gene is located at 3p26, which is demonstrated to be a candidate for prostate cancer susceptibility in Finnish prostate cancer families [17]. In review of previous researches, biological role and mechanism of CHL1 gene are issues in different human cancers. In ovarian cancer, Emily et al. proposed that CHL1 gene could not be identified as the tumor suppressor gene because somatic mutations of the gene were not identified [24]. On the other side, Sencheoko et al. investigated that CHL1 gene was a putative tumor suppressor in growth of ovarian tumor [17]. Meanwhile, because of the loss of 3p26.3, CHL1 gene was also reported as a candidate 
Table 2: Distribution of CHL1 rs425366 and the association with lung cancer susceptibility for cases and controls in northeast of China

\begin{tabular}{llccccc}
\hline & Genotype & Case & Control & OR $(\mathbf{9 5 \% C I})^{*}$ & P-value & HWD \\
\hline rs425366 & GG & $188(25.34)$ & $213(31.37)$ & Ref & 0.958 \\
& GT & $388(52.29)$ & $334(49.19)$ & $1.310(1.025,1.674)$ & 0.031 \\
TT & $166(22.37)$ & $132(19.44)$ & $1.433(1.060,1.938)$ & 0.019 \\
Dominant model & & & $1.343(1.065,1.694)$ & 0.013 \\
Recessive & & $1.194(0.924,1.544)$ & 0.175 \\
model & & & \\
Allele & & $1.196(1.032,1.387)$ & 0.018 \\
model & & & & \\
\hline
\end{tabular}

*Adjusted by for age and gender, OR and 95\% CI were calculated by logistic regression.

Table 3: Stratified analysis of CHL1 rs425366 and lung cancer susceptibility in northeast of China

\begin{tabular}{|c|c|c|c|c|c|}
\hline Histology & Genotype & Case & Control & OR $(95 \% \text { CI })^{*}$ & $P$-value \\
\hline \multirow{6}{*}{ adenocarcinoma } & GG & $113(24.89)$ & $213(31.37)$ & Ref & \\
\hline & GT & $236(51.98)$ & $334(49.19)$ & $1.293(0.973,1.720)$ & 0.077 \\
\hline & TT & $105(23.13)$ & $132(19.44)$ & $1.477(1.047,2.084)$ & 0.026 \\
\hline & Dominant model & & & $1.336(1.021,1.750)$ & 0.035 \\
\hline & $\begin{array}{l}\text { Recessive } \\
\text { model }\end{array}$ & & & $1.234(0.922,1.652)$ & 0.157 \\
\hline & $\begin{array}{l}\text { Allele } \\
\text { model }\end{array}$ & & & $1.207(1.018,1.430)$ & 0.030 \\
\hline \multirow{6}{*}{$\begin{array}{l}\text { squamous cell } \\
\text { carcinoma }\end{array}$} & GG & $42(25.61)$ & $213(31.37)$ & Ref & \\
\hline & GT & $83(50.61)$ & $334(49.19)$ & $1.271(0.840,1.925)$ & 0.257 \\
\hline & TT & $39(23.78)$ & $132(19.44)$ & $1.515(0.918,2.503)$ & 0.104 \\
\hline & Dominant model & & & $1.340(0.904,1.985)$ & 0.145 \\
\hline & $\begin{array}{l}\text { Recessive } \\
\text { model }\end{array}$ & & & $1.274(0.842,1.928)$ & 0.252 \\
\hline & $\begin{array}{l}\text { Allele } \\
\text { model }\end{array}$ & & & $1.224(0.957,1.565)$ & 0.107 \\
\hline \multirow{6}{*}{$\begin{array}{l}\text { small cell lung } \\
\text { cancer }\end{array}$} & GG & $26(28.26)$ & $213(31.37)$ & Ref & \\
\hline & GT & $51(55.43)$ & $334(49.19)$ & $1.258(0.757,2.092)$ & 0.375 \\
\hline & TT & $15(16.31)$ & $132(19.44)$ & $0.950(0.478,1.888)$ & 0.883 \\
\hline & Dominant model & & & $1.168(0.717,1.903)$ & 0.533 \\
\hline & $\begin{array}{l}\text { Recessive } \\
\text { model }\end{array}$ & & & $0.792(0.439,1.430)$ & 0.440 \\
\hline & $\begin{array}{l}\text { Allele } \\
\text { model }\end{array}$ & & & $0.996(0.728,1.364)$ & 0.981 \\
\hline
\end{tabular}

${ }^{\circ}$ Adjusted by age and gender, OR and 95\% CI were calculated by logistic regression

tumor suppressor gene in oral squamous cell carcinoma and esophageal squamous cell carcinoma [25, 26]. Genome Wide Association Study (GWAS) had found that CHL1 gene polymorphism had a link with lung cancer. In previous study, Vera N. Senchenko et al. demonstrated that CHL1 expression and CHL1 mRNA both decreased in lung cancer [17]. Moreover, the frequency of CHL1 mRNA decrease was different in different histology [17]. This controversial conclusion might be related to different ethnic, human cancers and life habits. 
Table 4: The effect of CHL1 rs425366 on lung cancer susceptibility in smokers and non-smokers in northeast of China

\begin{tabular}{|c|c|c|c|c|c|c|}
\hline & & Genotype & Case & Control & OR $(95 \% \text { CI })^{*}$ & $P$-value \\
\hline \multirow{12}{*}{ smoking } & \multirow{6}{*}{ yes } & GG & $30(27.78)$ & $144(32.43)$ & Ref & \\
\hline & & GT & $50(46.30)$ & $216(48.65)$ & $1.035(0.532,2.017)$ & 0.918 \\
\hline & & $\mathrm{TT}$ & $28(25.92)$ & $84(18.92)$ & $1.797(0.805,4.011)$ & 0.153 \\
\hline & & Dominant model & & & $1.227(0.660,2.282)$ & 0.518 \\
\hline & & $\begin{array}{l}\text { Recessive } \\
\text { model }\end{array}$ & & & $1.775(0.896,3.520)$ & 0.100 \\
\hline & & $\begin{array}{l}\text { Allele } \\
\text { model }\end{array}$ & & & $1.333(0.890,1.995)$ & 0.163 \\
\hline & \multirow{6}{*}{ no } & GG & $156(24.88)$ & $121(32.10)$ & Ref & \\
\hline & & GT & $335(53.43)$ & $184(48.81)$ & $1.514(1.119,2.049)$ & 0.007 \\
\hline & & TT & $136(21.69)$ & $72(19.09)$ & $1.538(1.056,2.242)$ & 0.025 \\
\hline & & Dominant model & & & $1.522(1.142,2.027)$ & 0.004 \\
\hline & & $\begin{array}{l}\text { Recessive } \\
\text { model }\end{array}$ & & & $1.175(0.852,1.622)$ & 0.326 \\
\hline & & $\begin{array}{l}\text { Allele } \\
\text { model }\end{array}$ & & & $1.248(1.039,1.499)$ & 0.018 \\
\hline
\end{tabular}

${ }^{*}$ Adjusted by age and gender, OR and 95\% CI were calculated by logistic regression

In this paper, we explored that there was a significant positive correlation between rs425366 polymorphism and lung cancer susceptibility in northeast of China. Additionally, individuals carrying at least one T allele (GT/TT) were less likely to suffer from lung cancer, comparing with individuals carrying GG genotype.

Furthermore, the stratified analysis results showed that $\mathrm{T}$ allele of rs 425366 had a 1.477 -fold risk of lung adenocarcinoma. However, no statistical associations were observed between GT genotype and lung adenocarcinoma. There was no evident correlation between lung squamous cell carcinoma, small cell lung cancer and gene polymorphism. These conflicting results might be due to the limited sample sizes. Thus, larger population is warranted to confirm the results in the future.

Tobacco carcinogens in smoking could result in gene mutations [27]. Individuals who exposed to tobacco trend to develop lung cancer [28]. Finally, we dissected the effect of gene-environment in lung cancer. However, our results indicated that non-smoking individuals carrying rs425366 GT and TT genotypes may have more risk of lung cancer. There was no statistically significant effect between tobacco exposure and gene polymorphism in lung cancer susceptibility. There was no significant interaction between rs425366 polymorphism and tobacco exposure in northeast of China (The result was not shown; $P=0.140$ ). The impact of CHL1 gene polymorphism may modulate the function of tobacco exposure. Hence we need a larger sample for further study to manifest the mechanism of CHL1 gene.
However, there are several limitations in our present study. Firstly, the number of our sample involved is not large enough. We only obtained demographic information of northeast of China. Thus, larger sample sizes are necessary in the further research. Secondly, we adopted hospital-based study, which may lead to selection bias. Thirdly, we lacked other gene-environmental interaction to verify the connection between CHL1 gene and lung cancer. Hence rigorous research will be needed to clarify the speculation about CHL1 gene and lung cancer.

In conclusion, we demonstrated that there was a link between CHL1 gene and lung cancer susceptibility in northeast of China. Moreover, this study manifested that rs425366 in CHL1 gene may increase the risk of lung adenocarcinoma. However, the results should be verified in a larger population. In the future study, it will be especially necessary to investigate the biological function of CHL1 gene in lung cancer.

\section{MATERIALS AND METHODS}

\section{Subject data collection}

This hospital-based case-control study was performed in Shenyang, containing 742 cases and 679 controls. All patients were recruited from the First Affiliated Hospital of China Medical University, the Fourth Affiliated Hospital of China Medical University and Liaoning Cancer Hospital. The cases were histologically confirmed lung cancer between March 2010 and March 
2013. The controls were frequency-matched and recruited from the same hospitals. The questionnaires were set to gather specific demographic characteristics including age, gender, smoking status, pathologic type, etc. Subjects who had smoked more than 100 cigarettes in the lifetime were defined as smokers. Those who had smoked less than 100 cigarettes were defined as non-smokers. All studies were conformed by the local institutional review board and all involved patients signed informed consent agreement.

\section{DNA genotyping}

In this study, genomic DNA samples of all subjects were segregated by phenol chloroform methods. Taqman allelic discrimination assay was used to estimate SNP genotyping. PCR Taqman primers and probes were supplied by Applied Biosystems. The results were obtained by ABI 7500 Fast Real-time PCR System with the Sequence Detection Software. Gene magnification was heated at $95^{\circ} \mathrm{C}$ for $10 \mathrm{~min}, 53$ cycles at $92^{\circ} \mathrm{C}$ for $30 \mathrm{~s}$ and $60^{\circ} \mathrm{C}$ for 1 min. To maintain accuracy of analysis results, ten percent of samples were duplicated and the results were coherent.

\section{Statistical analysis}

The two sides $\chi^{2}$ test and $t$ test were conducted to examined the characteristics of cases and controls. Logistic regression model was used to evaluate the odd ratios (ORs) and 95\% confidence intervals (CIs). $P<0.05$ was defined as statistical significance. Hardy-Weinberg equilibrium for SNP was calculated by the goodness-of-fit $\chi^{2}$ test. SPSS 20.0 software was utilized to analyze all data.

\section{ACKNOWLEDGMENTS AND FUNDING}

This study was found by grant no. 81502878 from the National Nature Science Foundation of China and no. 201501017 from Doctoral Research Start Found Project of Liaoning Province. The author thanks Xiaowei Quan, Chang Zheng and Yangwu Ren for supporting the paper and Zhihua Yin and Baosen Zhou for providing data and technology.

\section{CONFLICTS OF INTEREST}

We declare that we have no conflicts of interest.

\section{REFERENCES}

1. Shen M, Ren X. Highlights on immune checkpoint inhibitors in non-small cell lung cancer. Tumour Biol. 2017; 39:1010428317695013. https://doi. org/10.1177/1010428317695013.

2. Siegel RL, Miller KD, Jemal A. Cancer statistics, 2016. CA Cancer J Clin. 2016; 66:7-30. https://doi.org/10.3322/ caac. 21332 .
3. Lam WK, White NW, Chan-Yeung MM. Lung cancer epidemiology and risk factors in Asia and Africa. Int $\mathrm{J}$ Tuberc Lung Dis. 2004; 8:1045-57.

4. Chen W, Zhang S, Zou X. [Estimation and projection of lung cancer incidence and mortality in China]. [Article in Chinese]. Zhongguo Fei Ai Za Zhi. 2010; 13:488-93.

5. Gao Y, Zhang JF, Li QC, Liu JJ, Liu LL, Yang XF, Jiang HM, Zheng HC. The clinicopathological and prognostic features of Chinese and Japanese inpatients with lung cancer. Oncotarget. 2016; 7:67425-34. https://doi. org/10.18632/oncotarget.11850.

6. Qin HL, Zhu JJ, Zeng YY, Du WW, Shen D, Lei Z, Qian Q, Huang JA, Liu ZY. Aberrant promoter methylation of hOGG 1 may be associated with increased risk of non-small cell lung cancer. Oncotarget. 2017; 8: 8330-41. https://doi. org/10.18632/oncotarget.14177.

7. Cavalheri V, Granger C. Preoperative exercise training for patients with non-small cell lung cancer. Cochrane Database Syst Rev. 2017; 6:CD012020. https://doi. org/10.1002/14651858.CD012020.pub2.

8. Liang H, Guan P, Yin Z, Li X, He Q, Zhou B. Risk of lung cancer following nonmalignant respiratory conditions among nonsmoking women living in Shenyang, Northeast China. J Womens Health (Larchmt). 2009; 18:1989-95. https://doi.org/10.1089/jwh.2008.1355.

9. Tian F, Zhang Y, Ren Y, Shen L, Wu W, Zhou B. N-Acetyltransferase 2 (NAT2) gene polymorphism and exposure to smoking in lung cancer of Chinese males. Med Oncol. 2014; 31:90. https://doi.org/10.1007/s12032-0140090-9.

10. Liu J, Wang X, Ren Y, Li X, Zhang X, Zhou B. Effect of single nucleotide polymorphism Rs189037 in ATM gene on risk of lung cancer in Chinese: a case-control study. PLoS One. 2014; 9:e115845. https://doi.org/10.1371/journal. pone.0115845.

11. Molina JR, Yang P, Cassivi SD, Schild SE, Adjei AA. Nonsmall cell lung cancer: epidemiology, risk factors, treatment, and survivorship. Mayo Clin Proc. 2008; 83:584-94. https:// doi.org/10.1016/S0025-6196(11)60735-0.

12. Zhao MM, Zhang Y, Shen L, Ren YW, Li XL, Yin ZH, Zhou BS. Genetic variations in TERT-CLPTM1L genes and risk of lung cancer in a Chinese population. Asian Pac J Cancer Prev. 2014; 15:2809-13. https://doi.org/10.7314/ APJCP.2014.15.6.2809.

13. Yin Z, Zhou B, He Q, Li M, Guan P, Li X, Cui Z, Xue X, Su M, Ma R, Bai W, Xia S, Jiang Y, et al. Association between polymorphisms in DNA repair genes and survival of non-smoking female patients with lung adenocarcinoma. BMC Cancer. 2009; 9:439. https://doi.org/10.1186/14712407-9-439.

14. Zheng C, Li X, Xia L, Fang X, Quan X, Yin Z, Zhao Y, Zhou B. Polymorphisms of pri-miR-219-1 are associated with the susceptibility and prognosis of non-small cell lung cancer in a Northeast Chinese population. Oncotarget. 2017; 8:56533-41. https://doi.org/10.18632/oncotarget.17035. 
15. Pronina IV, Klimov EA, Burdennyy AM, Beresneva EV, Fridman MV, Ermilova VD, Kazubskaya TP, Karpukhin AV, Braga EA, Loginov VI. [Methylation of the genes for the microRNAs miR-129-2 and miR-9-1, changes in their expression, and activation of their potential target genes in clear cell renal cell carcinoma]. [Article in Russian]. Mol Biol (Mosk). 2017; 51:73-84. https://doi.org/10.7868/ S0026898416060161.

16. Huang X, Zhu LL, Zhao T, Wu LY, Wu KW, Schachner M, Xiao ZC, Fan M. CHL1 negatively regulates the proliferation and neuronal differentiation of neural progenitor cells through activation of the ERK1/2 MAPK pathway. Mol Cell Neurosci. 2011; 46:296-307. https://doi. org/10.1016/j.men.2010.09.013.

17. Senchenko VN, Krasnov GS, Dmitriev AA, Kudryavtseva AV, Anedchenko EA, Braga EA, Pronina IV, Kondratieva TT, Ivanov SV, Zabarovsky ER, Lerman MI. Differential expression of CHL1 gene during development of major human cancers. PLoS One. 2011; 6:e15612. https://doi. org/10.1371/journal.pone.0015612.

18. He LH, Shi YH, Jia YS. [The progress about CHL1 gene in cancer and other diseases]. [Article in Chinese]. Sheng Li Ke Xue Jin Zhan. 2016; 47:74-76.

19. Long MJ, Wu FX, Li P, Liu M, Li X, Tang H. MicroRNA10a targets CHL1 and promotes cell growth, migration and invasion in human cervical cancer cells. Cancer Lett. 2012; 324:186-96. https://doi.org/10.1016/j.canlet.2012.05.022.

20. Pronina IV, Loginov VI, Burdennyy AM, Fridman MV, Senchenko VN, Kazubskaya TP, Kushlinskii NE, Dmitriev AA, Braga EA. DNA methylation contributes to deregulation of 12 cancer-associated microRNAs and breast cancer progression. Gene. 2017; 604:1-8. https://doi. org/10.1016/j.gene.2016.12.018.

21. Martín-Sánchez E, Mendaza S, Ulazia-Garmendia A, Monreal-Santesteban I, Blanco-Luquin I, Córdoba A, Vicente-García F, Pérez-Janices N, Escors D, Megías D, López-Serra P, Esteller M, Illarramendi JJ, Guerrero-Setas D. CHL1 hypermethylation as a potential biomarker of poor prognosis in breast cancer. Oncotarget. 2017; 8:15789-801. https://doi.org/10.18632/oncotarget.15004.
22. He LH, Ma Q, Shi YH, Ge J, Zhao HM, Li SF, Tong ZS. CHL1 is involved in human breast tumorigenesis and progression. Biochem Biophys Res Commun. 2013; 438:433-38. https://doi.org/10.1016/j.bbrc.2013.07.093.

23. Chen J, Fu L, Zhang LY, Kwong DL, Yan L, Guan XY. Tumor suppressor genes on frequently deleted chromosome $3 p$ in nasopharyngeal carcinoma. Chin J Cancer. 2012; 31:215-22. https://doi.org/10.5732/cjc.011.10364.

24. Manderson EN, Birch AH, Shen Z, Mes-Masson AM, Provencher D, Tonin PN. Molecular genetic analysis of a cell adhesion molecule with homology to L1CAM, contactin 6, and contactin 4 candidate chromosome 3 p26pter tumor suppressor genes in ovarian cancer. Int $\mathbf{J}$ Gynecol Cancer. 2009; 19:513-25. https://doi.org/10.1111/ IGC.0b013e3181a3cd38.

25. Uchida K, Oga A, Nakao M, Mano T, Mihara M, Kawauchi S, Furuya T, Ueyama Y, Sasaki K. Loss of 3 p26.3 is an independent prognostic factor in patients with oral squamous cell carcinoma. Oncol Rep. 2011; 26:463-69. https://doi.org/10.3892/or.2011.1327.

26. Qin YR, Fu L, Sham PC, Kwong DL, Zhu CL, Chu KK, Li Y, Guan XY. Single-nucleotide polymorphism-mass array reveals commonly deleted regions at 3 p22 and 3 p14.2 associate with poor clinical outcome in esophageal squamous cell carcinoma. Int J Cancer. 2008; 123:826-30. https://doi.org/10.1002/ijc.23577.

27. Pfeifer GP, Denissenko MF, Olivier M, Tretyakova N, Hecht SS, Hainaut P. Tobacco smoke carcinogens, DNA damage and p53 mutations in smoking-associated cancers. Oncogene. 2002; 21:7435-51. https://doi.org/ 10.1038/ sj.onc. 1205803

28. Szabo E, Mao JT, Lam S, Reid ME, Keith RL. Chemoprevention of lung cancer: Diagnosis and management of lung cancer, 3rd ed: American College of Chest Physicians evidence-based clinical practice guidelines. Chest. 2013; 143:e40S-e60S. https://doi. org/10.1378/chest.12-2348. 